\title{
Development of thirteen
} polymorphic microsatellite markers for the Seychelles endangered and endemic jellyfish tree Medusagyne oppositifolia (Medusagynaceae)

\section{Journal Article}

Author(s):

Finger, Aline; Ghazoul, Jaboury; Todd, Mark; Kaiser-Bunbury, Christopher; Kettle, Chris J.

Publication date:

2010

Permanent link:

https://doi.org/10.3929/ethz-b-000027059

Rights / license:

In Copyright - Non-Commercial Use Permitted

Originally published in:

Conservation Genetics Resources 2(S1), https://doi.org/10.1007/s12686-009-9120-x 


\title{
Development of thirteen polymorphic microsatellite markers for the Seychelles endangered and endemic jellyfish tree Medusagyne oppositifolia (Medusagynaceae)
}

\author{
Aline Finger $\cdot$ Jaboury Ghazoul $\cdot$ Mark Todd $\cdot$ \\ Christopher Kaiser-Bunbury $\cdot$ Chris Kettle
}

Received: 2 October 2009/Accepted: 4 October 2009/Published online: 30 October 2009

(C) Springer Science+Business Media B.V. 2009

\begin{abstract}
The jellyfish tree Medusagyne oppositifolia is a flagship species of the Seychelles, being not only extremely rare and critically endangered, but also representing a monospecific endemic family, Medusagynaceae. The species survives in four populations on the Island of Mahé, where the total number of reproductive adults is 89 . Natural regeneration is only known for the largest of these populations. Understanding the mechanisms driving the lack of natural regeneration in this species has great conservation relevance. We developed thirteen polymorphic microsatellite loci for this species to enable studies of historic and contemporary gene flow. The number of alleles per locus ranged from 2 to 15 (mean of 6.62 per locus) with an average polymorphic information content of 0.54 across loci. Expected heterozygosity ranged from 0.12 to 0.66 with only two of the 13 loci showing deviation from Hardy-Weinberg expectation. The markers will help to provide a better understanding of the significance of historic distributions, gene flow and recent anthropogenic habitat degradation for the in situ and ex-situ conservation of this flagship tree species.
\end{abstract}

Keywords Microsatellites - Medusagyne oppositifolia . Population genetics - Seychelles · Gene flow

A. Finger $(\bowtie) \cdot$ J. Ghazoul · C. Kaiser-Bunbury · C. Kettle ETH Zürich, ITES-Ecosystem Management, Universitätsstrasse 16, 8092 Zurich, Switzerland e-mail: aline.finger@env.ethz.ch

M. Todd

Genetic Identification Services, Chatsworth, CA 91311, USA
Medusagyne oppositifolia Baker (Medusagynaceae) is one of the rarest and most threatened tree species in the world. Medusagynaceae is a monospecific family endemic to the Seychelles. Its evolutionary history remains somewhat enigmatic (Fay et al. 1997). It is commonly known as the jellyfish tree, the name deriving from the seed capsule which resembles an inverted medusa. As an endemic and unique species it has become a flagship species of the Seychelles.

The species is distributed on granitic outcrops (inselbergs) in four relatively isolated populations on the main island of Mahé. A total number of 89 adult trees survive with 77 individuals occurring in a single population. The species is thought to have a naturally fragmented population structure as it has never been recorded on forested slopes surrounding inselbergs. Its wind dispersed seeds and pollen could make it less sensitive to the deleterious genetic consequences of habitat fragmentation, traits commonly associated with long distance gene flow. Owing to an absence of historical records the extent of decline of M. oppositifolia in recent decades is uncertain, but a decline is clear for three of the four populations which now contain only 2-7 mature individuals with no sign of seedlings or saplings. Recruitment is only observed in the largest population.

Our work aims to investigate the constraints to natural regeneration in this flagship species through a better understanding of the reproductive ecology and specifically, historic genetic differentiation, contemporary gene flow by pollen dispersal, and genetic diversity among remaining populations.

To this end, we describe the characterization of 13 microsatellite markers for M. oppositifolia. Enriched libraries were made by Genetic Identification Services (http://www. genetic-id-services.com) from size selected (300-750 bp) 
genomic DNA ligated into the Hind III site of a pUC19 plasmid and enriched using magnetic bead capture (CPG, Inc., Lincoln Park, New Jersey) with biotin-labelled CA(15), Biotin-GA(15), Biotin-AAC(12) and Biotin-TAGA(8). In total, 102 different microsatellite-containing clones were identified from the two di-nucleotide and two tri-nucleotide repeat libraries. The libraries all contain between 10,000 and 15,000 recombinant cells. Plasmids from 96 positive clones were sequenced and primers designed for 86 microsatellitecontaining clones using DesignerPCR version 1.03 (Research Genetics, Inc), of which 24 were tested for polymorphism. Of these 24 the 13 most promising loci were optimized. Eight primers were fluorescently labelled at their $5^{\prime}$-end and five were labeled using an M13-tag at its $5^{\prime}$-end following Schuelke (2000; Table 1). Polymorphism of the 13 selected primers were evaluated using all adult trees of 89 M. oppositifolia samples collected from the four different sites on Mahé.
Leaf genomic DNA was extracted from M. oppositifolia $(n=89)$ using the QIAGEN DNeasy Plant Maxi Kit, following the manufacturer's protocol. PCRs for the fluorescence labeled primers were carried out in $10 \mu \mathrm{L}$ reactions with, $2 \mu \mathrm{L}$ of $1 \times$ PCR buffer (Promega colorless Flexi GoTaq PCR buffer), $2 \mathrm{mM} \mathrm{MgCl}, 0.2 \mu \mathrm{M}$ dNTPs, $0.6 \mu \mathrm{M}$ of each primer, $0.025 \mathrm{U}$ Taq polymerase (Promega), and $1 \mu \mathrm{L}$ DNA template (c. $10 \mathrm{ng}$ ). Cycling conditions were as follows: $1 \times\left(94^{\circ} \mathrm{C}\right.$ for $\left.3 \mathrm{~min}\right), 35 \times\left(94^{\circ} \mathrm{C}\right.$ for $40 \mathrm{~s}$, primer-specific temperature $\left(57^{\circ} \mathrm{C}\right)$ for $40 \mathrm{~s}, 72^{\circ} \mathrm{C}$ for $30 \mathrm{~s}), 1 \times\left(72^{\circ} \mathrm{C}\right.$ for $4 \mathrm{~min}$; Table 1$)$ carried out in a Bio-Rad Dyad Cycler. PCRs for the M13 primers were carried out in $10 \mu \mathrm{L}$ reactions with $2 \mu \mathrm{L}$ of $1 \times$ PCR buffer (Promega colorless Flexi GoTaq PCR buffer), $15 \mathrm{mM}$ $\mathrm{MgCl} 2,0.2 \mu \mathrm{M}$ dNTPs, $0.2 \mu \mathrm{L}$ of the $0.04 \mu \mathrm{M}$ M13 forward primer, $0.8 \mu \mathrm{L}$ of the $0.16 \mu \mathrm{M}$ reward primer and $0.8 \mu \mathrm{L}$ of the $0.16 \mu \mathrm{M}$ M13 primer, $0.025 \mathrm{U}$ Taq polymerase (Promega), and $2 \mu \mathrm{L}$ DNA template (c. $10 \mathrm{ng}$ ).

Table 1 Characteristics of 13 polymorphic microsatellite loci in Medusagyne oppositifolia

\begin{tabular}{|c|c|c|c|c|c|c|c|c|c|}
\hline Locus & $\begin{array}{l}\text { GenBank } \\
\text { Accession no. }\end{array}$ & Primer sequence $\left(5^{\prime}-3^{\prime}\right)$ & Repeat motif & $\begin{array}{l}\text { Size range } \\
\text { (bp) }\end{array}$ & $\operatorname{Ta}\left({ }^{\circ} \mathrm{C}\right)$ & $A$ & $H_{\mathrm{o}}$ & $H_{\mathrm{e}}$ & PIC \\
\hline$A 114$ & GU045577 & $\begin{array}{l}\text { F AAG CAA GCA CCT AAG ACA GTC } \\
\text { R TTG ATT CGT TTA CGG TTG AG }\end{array}$ & $(\mathrm{TC})_{18}(\mathrm{CA})_{16}$ & $85-115$ & 57 & 7 & 0.28 & 0.42 & 0.73 \\
\hline$B 107$ & GU045578 & $\begin{array}{l}\text { F ATG TCC AAT CTC TCT CGT CAA C } \\
\text { R ACC CCT GTC GTT TAG AAT CTG }\end{array}$ & $(\mathrm{CT})_{17}$ & $146-161$ & 57 & 6 & 0.80 & 0.56 & 0.53 \\
\hline C107 & GU045580 & $\begin{array}{l}\text { F TTG CTT TTG GCA CTG AAT C } \\
\text { R CTT CCC TCC TTT TCT GAC G }\end{array}$ & $(\mathrm{GTT})_{12}$ & $173-182$ & 57 & 2 & 0.35 & 0.28 & 0.29 \\
\hline$D 12$ & GU045574 & $\begin{array}{l}\text { F GTT ATT GCA CTA AAG CCT CATC } \\
\text { R CTT CGT ATA GAT TGC CTT AAC G }\end{array}$ & $(\mathrm{TAGA})_{6}$ & $226-242$ & 57 & 5 & 0.58 & 0.49 & 0.60 \\
\hline$D 118$ & GU045581 & $\begin{array}{l}\text { F TTG GCC CTT GCT TTC ATA G } \\
\text { R GGT GAC CTC TTG ATC CAA CAT }\end{array}$ & $(\mathrm{CTAT})_{9}$ & $103-119$ & 57 & 5 & 0.48 & 0.37 & 0.70 \\
\hline A107 & GU045576 & $\begin{array}{l}\text { F GAT GCC GAT TTC ATG TAC G } \\
\text { R TCG ATT CAC AAC GCT CTT C }\end{array}$ & $(\mathrm{CA})_{19}$ & 133-139 & 57 & 4 & 0.21 & 0.39 & 0.39 \\
\hline D6 & GU045573 & $\begin{array}{l}\text { F GCA CGT ATT GCA CAC ACA C } \\
\text { R TCG AAA AGC ATA GAC TAA CAG C }\end{array}$ & $(\text { TAGA })_{9}$ & $289-305$ & 57 & 4 & 0.51 & 0.42 & 0.42 \\
\hline B112 & GU045579 & $\begin{array}{l}\text { F ACC CAT AAA AGC CAC CAC } \\
\text { R GCT CAG GTT GAA CAG GTT AG }\end{array}$ & $(\mathrm{GA})_{19}$ & 150-202 & 57 & 15 & 0.69 & 0.59 & 0.86 \\
\hline A9 (M13) & GU045571 & $\begin{array}{l}\text { F CTT CCT CAC CCA CCT GAC } \\
\text { R GCA ATC TCT CAT TCC TTT CTT }\end{array}$ & $(\mathrm{GT})_{19}$ & $240-276$ & 56 & 11 & 0.59 & 0.59 & 0.66 \\
\hline$B 8 a$ (M13) & GU045575 & $\begin{array}{l}\text { F ACC CCC TCT CTA TCT TCT TTC } \\
\text { R CAA AAT CGC CAC AAA TTC }\end{array}$ & $(\mathrm{CTGT})_{3}(\mathrm{CT})_{12}$ & $166-178$ & 56 & 7 & 0.70 & 0.64 & 0.50 \\
\hline C12 (M13) & GU045572 & $\begin{array}{l}\text { F ACC GAA TTA GGG CTA GGA TG } \\
\text { R ACA GCA ACA GCA ACT CCT GT }\end{array}$ & $(\mathrm{GTT})_{7}$ & $206-218$ & 56 & 2 & 0.17 & 0.12 & 0.03 \\
\hline A4 (M13) & GU045570 & $\begin{array}{l}\text { F: GCA ATC CTC TCA TCA ATA CCA } \\
\text { R: ACG CAA ATA GTT TAC TCC TTC G }\end{array}$ & $(\mathrm{CA})_{15}(\mathrm{TA})_{4}(\mathrm{GA})_{8}$ & $235-273$ & 56 & 10 & 0.52 & 0.66 & 0.74 \\
\hline A7 (M13) & GU045569 & $\begin{array}{l}\text { F ATC CGT AAA GTG CAT GGT TTC } \\
\text { R AAG AAG TGG ATC GGA GTG ATG }\end{array}$ & $\begin{array}{l}(\mathrm{CACG})_{4}(\mathrm{CA})_{29} \\
(\mathrm{TA})_{8}\end{array}$ & 254-286 & 56 & 7 & 0.40 & 0.43 & 0.63 \\
\hline
\end{tabular}

$F$ forward primer, $R$ reverse primer, $T_{a}$ annealing temperature, $A$ mean number of alleles, $H_{\mathrm{o}}$ observed heterozygosity, $H_{\mathrm{e}}$ expected heterozygostiy, PIC Polymorphism information content, 89 individuals were analysed for each locus 
Cycling conditions were as follows: $1 \times\left(95^{\circ} \mathrm{C}\right.$ for $\left.15 \mathrm{~min}\right)$, $30 \times\left(95^{\circ} \mathrm{C}\right.$ for $30 \mathrm{~s}$, primer-specific temperature $\left(56^{\circ} \mathrm{C}\right)$ for $45 \mathrm{~s}, 72^{\circ} \mathrm{C}$ for $\left.45 \mathrm{~s}\right), 8 \times\left(95^{\circ} \mathrm{C}\right.$ for $30 \mathrm{~s}$, primer-specific temperature $\left(53^{\circ} \mathrm{C}\right)$ for $45 \mathrm{~s}, 72^{\circ} \mathrm{C}$ for $\left.45 \mathrm{~s}\right), 1 \times\left(72^{\circ} \mathrm{C}\right.$ for 30 min; Table 1) carried out in a Bio-Rad Dyad Cycler. We used an ABI3730 for genotyping and Genemapper 3.5 software (Applied Biosystems) for fragment analysis.

Descriptive statistics (number of alleles, observed and expected heterozygosities), deviations from Hardy-Weinberg equilibrium (HWE) were generated using GenAlEx 6.2 (Peakall and Smouse 2006). The polymorphism information content (PIC) was calculated in Cervus 3.0 (Kalinowski et al. 2007). Linkage disequilibrium was checked, using GENEPOP (Raymond and Rousset 1995). All 13 loci were polymorphic with 2-15 alleles and a total number of 85 alleles detected over all populations for M. oppositifolia. Observed heterozygosity values ranged from 0.17 to 0.80 . There was no evidence for scoring error due to stuttering and no evidence for large allele dropout according to microchecker 2.2.3 (Oosterhout et al. 2004) but evidence for null alleles were detected for loci A107 and A114. Significant deviations from Hardy-Weinberg equilibrium (HWE, $P<0.05$ ) were detected in the same 2 loci (A114, A107). No significant linkage disequilibrium was detected suggesting that all 13 loci segregate independently of each other. These results indicate that these 13 primers will provide a valuable tool for evaluating genetic diversity and the reproductive ecology of this rare and emblematic tree species.
Acknowledgments We thank the Seychelles Government, especially Didier Dogley for permission to collect samples and Denis Matatiken of the Botanical Garden Section of the Ministry of Environment and Natural Resources (MENR) for advice. Special thanks as well to Terence Valentin, Damien Dudee and James Mougal for valuable assistance in the field. This research was funded under grant number ETH-07 08-01) ETH, Zürich.

\section{References}

Fay MF, Swensen SM, Chase MW (1997) Taxonomic affinities of Medusagyne oppositifolia (Medusagynaceae). Kew Bull 52:111120

Kalinowski ST, Taper ML, Marshall TC (2007) Revising how the computer program CERVUS accommodates genotyping error increases success in paternity assignment. Mol Ecol 16:10991106. doi:10.1111/j.1365-294x.2007.03089.x

Peakall R, Smouse PE (2006) GENEALEX 6: genetic analysis in Excel. Population genetic software for teaching and research. Mol Ecol Notes 6:288-295

Raymond M, Rousset F (1995) GENEPOP (version 1.2): population genetics software for exact tests and ecumenicism. J Hered 86:248-249

Schuelke M (2000) An economic method for the fluorescent labeling of PCR fragments. Nat Biotechnol 18:233-234

Van Oosterhout C, Hutchinson WF, Willis DPM, Shipley P (2004) MICRO-CHECKER (ver. 2.2.3): software for identifying and correcting genotyping errors in microsatellite data. Mol Ecol Notes 4:535-538 